Yu. Vorobyov, I. ShostaK, S. Kryvova, A. Zubanyov

\title{
DEVELOPMENT OF ONTOLOGICAL DECISION MAKING SYSTEM OF THE NEGOTIATION PROCESS ON COOPERATION PRODUCTION IN AIRCRAFT
}

Subject matter: means of information support for the negotiation process on the organization of cooperative production of aircraft. Goal: an outline of the process of developing effective means of information support for negotiations on cooperative production, which will provide financial savings, firstly, by reducing the negotiation time, and secondly, is reducing the likelihood of making irrational decisions that can lead to additional costs during project implementation. Tasks: Increase the efficiency of the negotiation process on the organization of cooperative production by creating a problem-oriented methodological basis, and on this basis software tools for the development, deployment and operation of the appropriate decision support system. Methods: system analysis and set theory, for the formal presentation of relevant information about the subject area "Negotiations on cooperative aircraft production"; ontological engineering, in particular the IDEF5 standard, as well as elements of expert systems technology, for building an ontological decision support system. Results: an aggregate of methodological tools for the synthesis of ontological decision support systems was developed during negotiations on the organization of cooperative production of aircraft, a scenario example of organizing an ontological dialogue in the environment of an ontological decision support system for defining an aircraft model as an object of cooperative production was given. Conclusions: the need to supplement the mathematical support of traditional negotiation support systems with special methodological means is shown to increase the efficiency of information support for the negotiation process on organizing cooperative production in aircraft construction; it is substantiated that for the program implementation of the system of information support for negotiations on the organization, it is advisable to use the ontological approach; the architecture of the intellectual core of the ontological decision support system for organizing the negotiation process for organizing the cooperative production of aircraft in the form of a hierarchy of frames, with the organization of knowledge-based inference by means of attached procedures is proposed; a scenario example of the formation of a decision on the choice of an aircraft model for the organization of cooperative production in the environment of an ontological decision support system is given.

Keywords: aircraft construction; cooperative production; decision support system; ontological approach; frame hierarchy; decision maker.

\section{Introduction}

Today, cooperative production is a fairly common form of industrial organization, in particular, aircraft construction. In aircraft construction, the efficiency of cooperative production largely depends on the proper level of organization of negotiations between subcontractors, as the cost of correcting incorrect decisions made during negotiations will increase during the project, and may result in unacceptably high values. A key feature of the negotiations on the organization of cooperative production (NOCP) is the need to directly involve, especially at the stage of project initiation, a significant number of narrow specialists - experts. This raises the issue of prompt coordination of different, often contradictory opinions of experts, which slows down the process of NOCP and negatively affects its effectiveness in terms of unreasonably high entertainment costs, especially when it comes to international projects.

This study is devoted to the organization of information support of the NOCP process by developing a specialized information environment, which will present the knowledge of experts on technical, technological, financial and social issues of NOCP organization, and means of manipulating this knowledge for the rapid formation of agreed solutions.

\section{Formulation of a scientific problem and its significance}

The problem of insufficient efficiency of the NOCP negotiation process arises due to, inter alia, the lack of specialized computer support tools, which in the formation of appropriate solutions, would allow to take into account the specifics of individual stages of NOCP, including the most critical stage - project initiation and subject area "Cooperative production in aircraft construction".

A constructive way to solve the stated problem is to develop an ontological decision support system (ODSS) on a set of issues of the NOCP organization.

Solving this problem by creating and using effective means of information support NOCP will save money, firstly, by reducing the time of negotiations, and secondly, by reducing the likelihood of irrational decisions that lead to additional costs during the project.

\section{Analysis of publications on the stated problem}

From the standpoint of situation analysis [1], NOCP is a process of exchanging views in order to reach an agreement on mutually beneficial cooperation.

The main distinguishing feature of NOCP from other types of negotiations is the presence of at least two participating parties with goals that do not coincide in part, personal interests, opinions and intentions. This partial disagreement is, in essence, a conflict. Another feature of the NOCP process is that they always occur, according to the classification of negotiation environments by D.O. Pospelov [2], in the most complex, transformed environment, which is problematic not only to create a deterministic description of the whole process, but also local models negotiations. The characteristics of the transformed environment are unstable and strongly 
depend on the actions of the participating agents. The second of these features determines the feasibility of using in the analysis of NOCP conflict management tools.

The process of computerization of negotiation processes in various spheres of human activity, except for the organization of production, has been going on for a relatively long time [3], and today in a number of subject areas successfully used decision support systems (DSS) in negotiations [4]. At the same time, the peculiarities of aircraft construction and, accordingly, the processes of management of cooperative aircraft production projects [5], do not allow to directly apply the available on the software market means of information support of negotiations at the stage of NOCP initiation.

The purpose of the article is to solve the problem, which is to increase the efficiency of the NOCP process, by creating a problem-oriented methodological basis, and on this basis - software tools for development, deployment and operation of the relevant ODSS.

\section{Materials and methods of the study}

Let's consider the process of creating an ODSS NOCP in the form of a fragment that reflects the formation of a number of solutions for the assembly of the aircraft (AC). We will describe this process in accordance with the requirements of the standard of ontological research IDEF5 [6], as well as using approaches that are well known in the practice of ontological engineering [7-10].

We will assume that the ODSS NOCP AC $F_{0 \text { s }}$ fragment includes three ontologies:

$$
F_{O S}=\left\{F_{O S}^{M}, F_{O S}^{T}, F_{O S}^{S u b}\right\}, F_{O S}^{M} \cap F_{O S}^{T} \cap F_{O S}^{S u b}=0,
$$

where $F_{O S}^{M}-$ metaontology "Types and models of $\mathrm{AC}$ "; $F_{o s}^{T}$ - ontology of tasks "Manufacturability of aircraft constructions"; $F_{O S}^{\text {Sub }}$ - subject area ontology "AC assembly".

In this case, for any ontology $\mathrm{F}$ in the $F_{O S}$ ODSS fragment $\forall F \mid F \subset F_{O C}$ it is true that

$$
F=\left\{f[1], f\left[(j+1)_{i}\right]\right\}, j_{i}=\overline{1, M_{i}} i=\overline{1, N},
$$

where $f[1]$ - root frame of the ontology $F$; $\left\{f\left[(j+1)_{i}\right]\right\}$ - descendant frames in any ontology that is part of $F_{O S} ; \quad i$ - aspect number to which the frame (set of frames) belongs; $j_{i}$ - sequence number of the frame in the aspect; $N$ - number of aspects of the ontology $F ; M_{i}$ - the number of frames in the $i$-th aspect of the ontology $F$.
Each frame $f\left[(j+1)_{i}\right]$ can be represented as a combination of two types of slots $\left\{S_{k}\right\}$ and $\left\{S_{l}\right\}$. In this case, the slots from the set $S_{k}$ inherit the features of higher-level frames and, thus, reflect the genus connections within the frame hierarchy; the set $S_{l}$ also contains its own slots of this frame. Obviously, any root frame $f[j]$ contains only its own slots $\left\{S_{l}\right\}$ :

$$
\begin{aligned}
& \forall f[j] \mid f[j] \in F, \quad f[j]=\left\{S_{l}\right\} ; \\
& \forall f\left[(j+1)_{i}\right] \mid f\left[(j+1)_{i}\right] \in F ; \\
& f\left[(j+1)_{i}\right]=\left\{\left\{S_{k}\right\},\left\{S_{l}\right\}\right\} ; \\
& k=\overline{1, K_{j_{i}}}, \quad l=\overline{\left(K_{j_{i}}+1\right), L_{j_{i}}},
\end{aligned}
$$

where $L_{j_{i}}$ is the number of frame slots $f\left[j_{i}\right]$.

The set of slots $\left\{S_{l}\right\}$ details the description of this or that ontological aspect, and also realizes communications with the lower hierarchical level.

One or more facets $C\left[j_{i}\right]$ are directly connected to any slot $S\left[j_{i}\right]$, and the number of facets determines the power of that slot. Facets are quantitative or qualitative restrictions on the characteristics determined by the slots.

Using the previously introduced notation, as well as methodological tools, considered in [11-13], we describe the ontological system ODSS in the form of a formal axiomatic theory of the first order $\Phi$ with a logical basis $\{\vee, \wedge, \rightarrow\}$.

Let the signature $\sigma^{(\cdot)}$ is given for any ontology $F_{O S}^{(\bullet)}$ that is part of an ontological system $F_{O S}$ where $(\bullet)$ can have the meaning of " $M$ ", " $T$ " or " $S u b$ ", indicating that the symbols of the formal theory belong to "Metaontology", "Ontology of Tasks" or "Ontology of Subject Area", respectively.

$$
\begin{aligned}
& \sigma^{(\bullet)}=\left\{F^{(\bullet)}[1], F^{(\bullet)}\left[2_{1}\right], \ldots, F^{(\bullet)}\left[5_{7}\right], S_{1}^{(\bullet)}[1], \ldots,\right. \\
& S_{4}^{(\bullet)}[1], S_{1}^{(\bullet)}\left[2_{1}^{1}\right], \ldots, S_{7}^{(\bullet)}\left[5_{7}^{4}\right], T_{1}^{(\bullet)}\left[2_{1}^{1}\right], \ldots, \\
& \left.T_{7}^{(\bullet)}\left[5_{7}^{4}\right], V_{1}^{(\bullet)}\left[2_{1}^{1}\right], \ldots, V_{7}^{(\bullet)}\left[5_{7}^{4}\right]\right\} .
\end{aligned}
$$

Such a description makes it possible to present a description of any ontology $F_{O S}^{(\cdot)}$ as a model $M^{(\cdot)}(\Phi)$ of the described theory $\Phi$. Logical inference within the ODSS NOCP AC fragment under consideration is performed by activating the attached procedures, which have the form of product rules:

$$
P_{O S} \supset P_{k} \cup P_{l},\left|P_{O S}\right|=\left|S_{O S}\right| \text {. }
$$


Attached procedures from the set $\left\{P_{k}\right\}$ belong to the type "Procedures - demons", and from the set $\left\{P_{l}\right\}-$ to the type "Procedures - servants", with a bijective reflection $G: P_{O S} \rightarrow S_{O S}$. Restrictions contained in facets are part of the antecedent rules - products from the set $\left\{P_{l}\right\}$.

Let's assume that all ontologies in the ODSS fragment have the same structure in the sense that they have the same number of aspects $N=4 M$ and, in addition, the number of frames representing each aspect.

In addition, we will assume that each ontology that is part of $F_{O S}$ is internally consistent, i.e. the following conditions are met for it:

1) all element names are defined in the glossary;

2) all files in the taxonomy are connected by hierarchical relations "is a"; at the top level of the taxonomic hierarchy, only one frame is defined;

3) for all elements defined in the ontology there are restrictions on their belonging to the frames;

4) frames and their elements have unique names;

5) all frames located at the lower level of the taxonomy have as a consequence of the attached procedures attributes included in the glossary of the ontological system;

6) restrictions within individual ontologies and the ontological system as a whole are consistent;

7) the associative connections between the frames that are part of different ontologies are explicitly given, these connections are described in the form of meta-rules.

Because the ODSS NOCP AC fragment is a dialog system by nature, the process of its operation consists in the iterative procedure of synthesis of text objects of the "REPORT" type by analyzing the corresponding objects of the "REQUEST" type. This analysis involves the consistent implementation within the ontological system of standard operations of ontological engineering: SEARCH; SAMPLE; CONNECTIONS; CUT OFF $[14,15]$.

The search operation involves:

1) analysis of the text object "REQUEST" in order to highlight a set of keywords (SKW);

2) reflection of SKW in terms of the glossary $V$ :

$$
V=\{\text { Term }\}, \text { Term }=(I D, \text { Keyword Set }, \text { Description }) \text {, }
$$

where $I D$ - term identifier (corresponds to the identifier of the concept included in the glossary); Keyword Set $=\{$ Keyword Entry $\}-$ a set of keywords belonging to a certain term; Keyword Entry $=($ Keyword ID, Keyword $) \quad-\quad$ a pair consisting of the keyword ID and the keyword itself; Description - description of the meaning of the term;

3) search in each ontology $F \supset F_{O C}$ for the names of the frames by $I D$, obtained after the previous step. In result

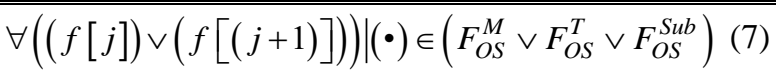

the set is formed $\left\{f\left[j_{i}\right]\right\}$ such that

$$
\exists q \in Q_{i}: \operatorname{Term}(q) \in V,
$$

where $S^{(s u b)}\left[3_{2}^{2}\right]$ - the identifier (ID) of the term corresponding to the frame name (the name of the frame $q$ element).

At the sampling stage, the microcontext of the "REPORT" object is formed by activating the meta-rules that reflect the associative connections between the elements $\left\{f\left[j_{i}\right]\right\}$ that are part of different ontologies:

1 ) in each ontology that is a part of $F_{O S}$, frames and their elements connected through meta-rules with frames of other ontologies are distinguished. Since the ontologies in the ontological system are of the same type and there are taxonomies, such an operation is performed in each taxonomy, starting from the root frame and ending with the terminal elements of the lower levels;

2) this step involves removing from the ontological system of existing contexts by forming an appropriate set of sets;

3) the sets obtained in the previous step are sorted by the number of frame names (and their elements) contained in them, which coincided with the terms of the glossary.

The connection operation involves the formation of the macro-context of the "REPORT" object by combining elements isolated and extracted from the ontological system at the previous stage.

The clipping operation is used to remove excess elements from the REPORT object.

Excess elements include the names of frames without specifying their slots, facets and procedures, elements without specifying their belonging to frames, as well as elements that do not meet the requirements of relevance.

When creating AC co-production projects, one of the most critical, relative to the overall effectiveness of NOCP, is the initiation stage of the project, at which the parties to the negotiations determine the specific AC model, based on the needs and capabilities of potential cooperants [5]. The main task of this stage is the complex consideration of a significant number of parameters characterizing $\mathrm{AC}$, the future object of CP. There is a problem of semantic combination of these parameters, because in nature (technical, technological, financial, social or mixed), they are heterogeneous.

The macrostructure of dialogue and ontological engineering procedures is given in table 1 , and the list of concepts used in the example of the dialogue scenario of the decision-making person (DMP) with ODSS NOCP AC - in table 2. 
Table 1. Macrostructure of dialogue and ontological engineering procedures for the choice of AC model for CP organization

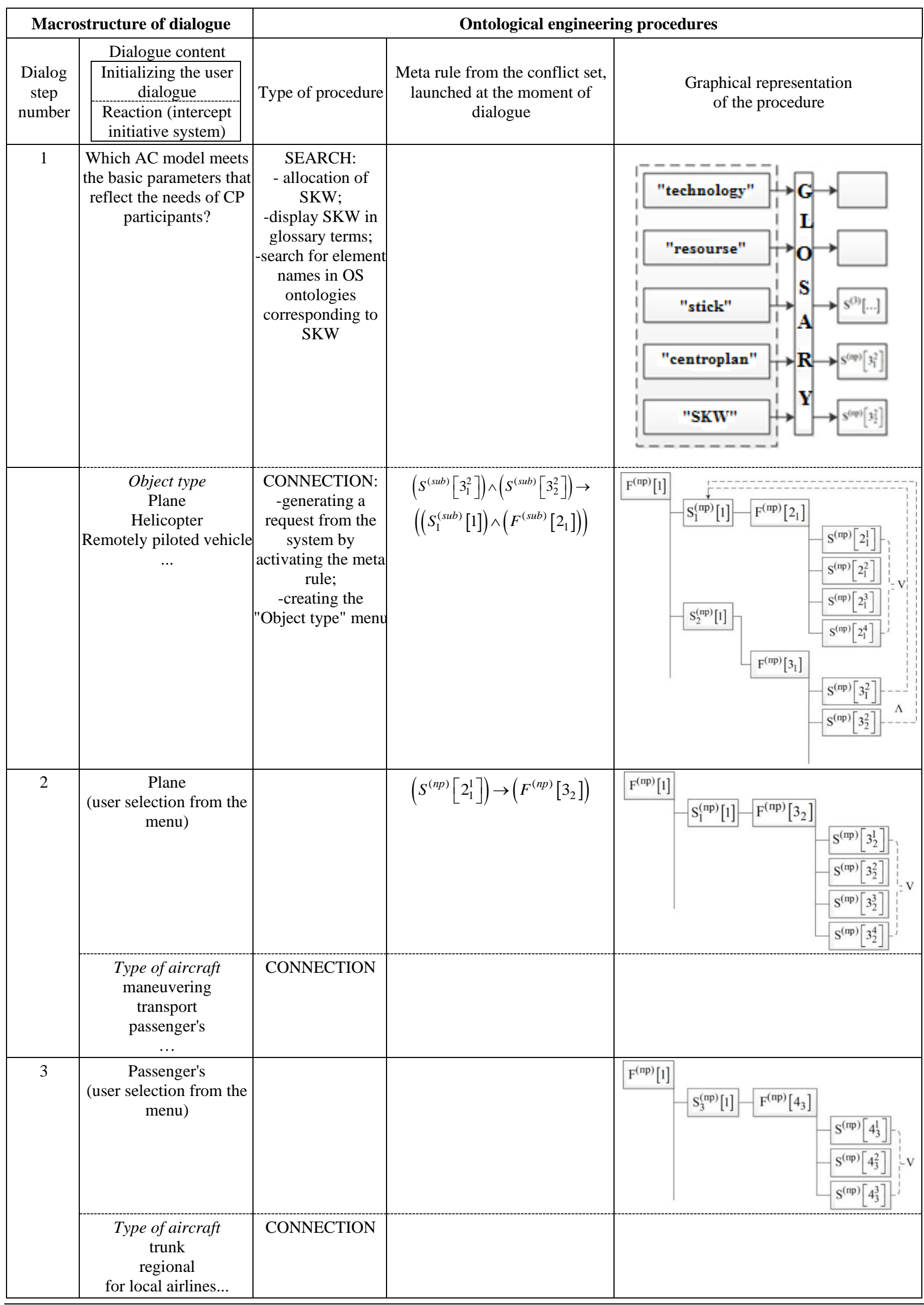


The end Table 1.

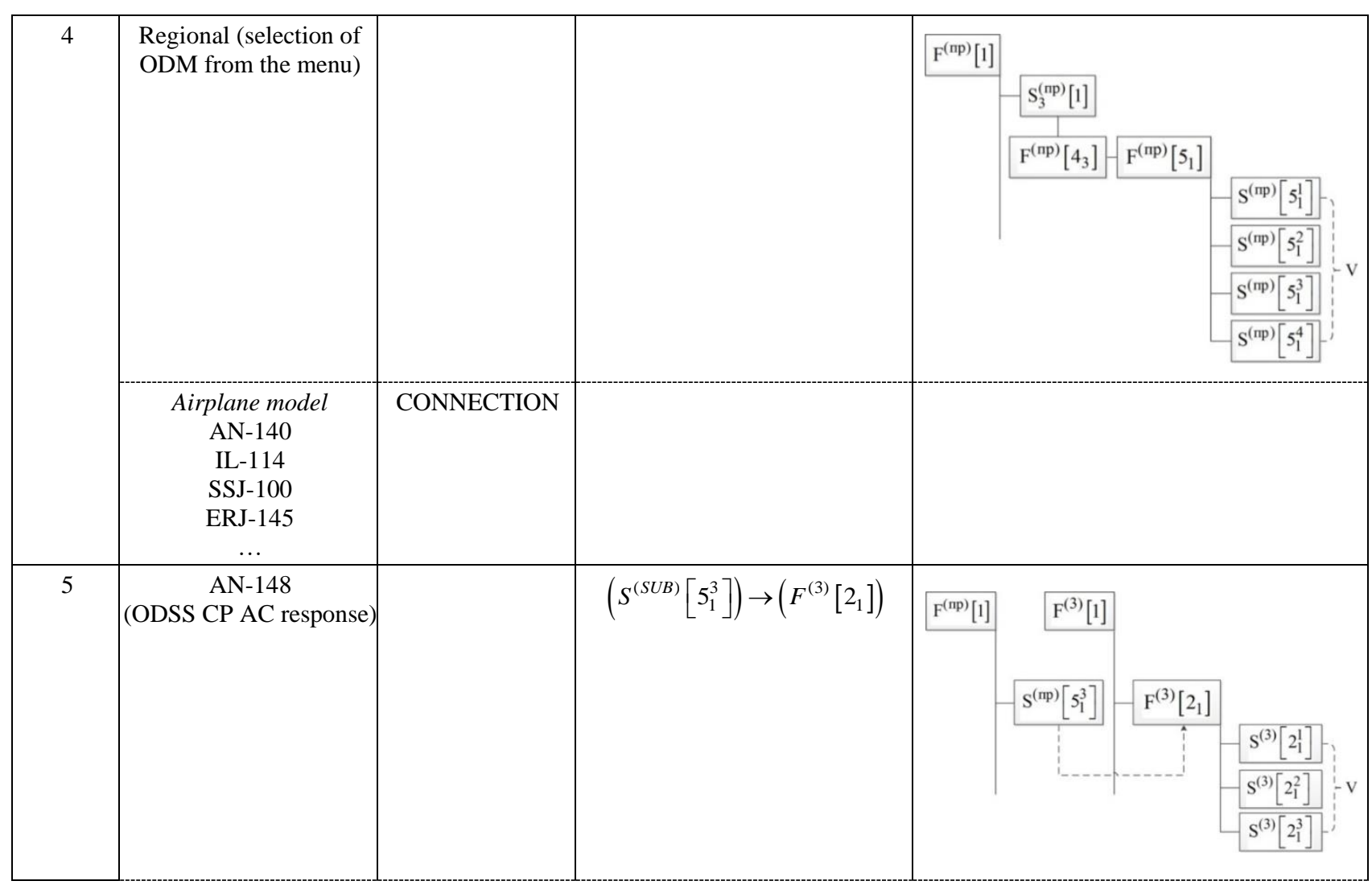

Table 2. A list of concepts used in the example of the ODM dialogue scenario with ODSS

The name of the concept and its position in ODDS

\begin{tabular}{|c|c|}
\hline 1 & \multirow[b]{2}{*}{ Assembly of aircraft structures } \\
\hline$F^{(s u b)}[1]$ & \\
\hline$S_{1}^{(s u b)}[1]$ & Aircraft \\
\hline$F^{(s u b)}\left[2_{1}\right]$ & Object type \\
\hline$S^{(s u b)}\left[2_{1}^{1}\right]$ & Plane \\
\hline$S^{(s u b)}\left[2_{1}^{2}\right]$ & Helicopter \\
\hline$S^{(s u b)}\left[2_{1}^{3}\right]$ & UAV \\
\hline \multicolumn{2}{|l|}{$\cdots$} \\
\hline$S_{2}^{(s u b)}[1]$ & Assembly units \\
\hline$F^{(s u b)}\left[3_{1}\right]$ & Wing \\
\hline$S^{(s u b)}\left[3_{1}^{2}\right]$ & Centroplan \\
\hline$S^{(s u b)}\left[3_{2}^{2}\right]$ & Negative part of the wing (NPW) \\
\hline$F^{(s u b)}\left[3_{2}\right]$ & Type of aircraft \\
\hline$S^{(s u b)}\left[3_{2}^{1}\right]$ & Maneuvering \\
\hline$S^{(s u b)}\left[3_{2}^{2}\right]$ & Transport \\
\hline
\end{tabular}




\begin{tabular}{|c|c|}
\hline$S^{(s u b)}\left[3_{2}^{3}\right]$ & Passenger's \\
\hline$S^{(s u b)}\left[3_{2}^{4}\right]$ & General aviation aircraft (GAA) \\
\hline \multicolumn{2}{|l|}{$\ldots$} \\
\hline$S_{3}^{(s u b)}[1]$ & Subsonic aircraft \\
\hline$F^{(s u b)}\left[4_{3}\right]$ & Types of subsonic aircraft \\
\hline$S^{(s u b)}\left[4_{3}^{1}\right]$ & Trunk \\
\hline$S^{(s u b)}\left[4_{3}^{2}\right]$ & Regional \\
\hline$S^{(s u b)}\left[4_{3}^{3}\right]$ & For local airlines \\
\hline \multicolumn{2}{|l|}{$\cdots$} \\
\hline$F^{(s u b)}\left[5_{1}\right]$ & Model range of regional aircraft \\
\hline$S^{(s u b)}\left[5_{1}^{1}\right]$ & AN-140 \\
\hline$S^{(s u b)}\left[5_{1}^{2}\right]$ & IL-114 \\
\hline$S^{(s u b)}\left[5_{1}^{3}\right]$ & SSJ-100 \\
\hline$S^{(s u b)}\left[5_{1}^{4}\right]$ & ERJ-145 \\
\hline \multicolumn{2}{|l|}{$\ldots$} \\
\hline$F^{(t)}[1]$ & The task of assembling aircraft structures \\
\hline
\end{tabular}

In the following scenario, ODSS NOCP AC forms the answer to the ATS question "Which AC model meets the basic parameters that reflect the needs of $\mathrm{CP}$ participants?"

\section{Conclusions and prospects for further research}

1. The necessity of supplementing the mathematical support of traditional systems of support of negotiations with special methodical means for increase of efficiency of information support of process of negotiations concerning the organization of cooperative production in aircraft building is shown.

2. It is substantiated that for software implementation of the NOCP information support system it is expedient to use the ontological approach.

3. It is proposed to build the intellectual core of the ontological decision support system for the NOCP AC process in the form of a hierarchy of frames with the organization of knowledge output using the attached procedures.

4. A scenario example of forming a decision on the choice of AC model for the organization of $\mathrm{CP}$ in the ODSS environment is given.

\section{References}

1. Whitty, S. J., Schulz, V. F. (2006), "The PM BOK CODE", 20th IPMA World Congress on Project Management, No. 1, P. 466-472.

2. Pospelov, D. A. (1986), Situational management: theory and practice, Moscow : Science, Ch. ed. Phys.-Math Lit., 288 p.

3. Eom, S. B. (1995), "Decision support systems research: reference disciplines and a cumulative tradition", The International Journal of Management Science, Vol. 23, No.5, P. 511-523.

4. Kislyakova, Y. V., Tarasov, B. V. (2005), "Computer systems for negotiation support", Applied Informatics, Moscow, No. 4, P. 46-51.

5. Krivova, S. G., Zubanov, O. E. (2019), "Approaches to the correction of early stages of science-intensive engineering projects", Technological systems, Kyiv, No. 4 (89), P. 45-49.

6. https://www.r-p-c.ru/resheniya/metodologiya-idef-integrated-definition-modelirovaniya-biznes-processov.html

7. Standard Upper Ontology Working Group (SUO) IEEE P1600.1, http://suo.ieee.org/ 
8. Gruber, T. R. (1995), "Toward Principles for the Design of Ontologies Used for Knowledge Sharing", International Journal Human-Computer Studies, No. 43 (5-6), P. 907-928.

9. Guarino, N. (1995), "Formal Ontology: Conceptual Analysis and Knowledge Representation", International Journal of Human-Computer Studies, No. 43 (5-6), P. 625-640.

10. Sowa, J. F. (1984), Conceptual Structures. Information Processing in Mind and Machine, Reading, MA : Addison Wesley.

11. Shostak, I., Kapitan, R,. Volobuyeva, L., Danova, M. (2018), "Ontological Approach to the Construction of Multi-Agent Systems for the Maintenance Supporting Processes of Production Equipment", In Proc. : IEEE International Scientific and Practical Conference "Problems of Infocommunications. Science and Technology" (PICS\&T-2018), Ukraine, Kharkiv, October 9-12, P. 209-214.

12. Shostak, I., Danova, M, Romanenkov, Y., Bugaienko, O., Volk, M., Karminska-Bielobrova, M. (2018), "Organization of information support for business processes at aviation enterprises by means of ontological engineering", EasternEuropean Journal of Enterprise Technologies, Vol. 2, No. 2 (92), P. 45-55. DOI: 10.15587/17294061.2018.126673

13. Pavlenko, V., Shostak, I., Morozova, O., Danova, M. (2018), "Information support for business processes on the virtual enterprises with the use of multi-agent technologies", Proc. DEpendable Systems, SERvices and Technologies DESSERT'2018. Ukraine, Kyiv May 24-27, IEEE Ukraine Section.

14. Vorobiev, Yu. A., Nechiporuk, N. V., Kobrin, V. N., Shostak, I. V. (2014), "Models of ontologies and an ontological decision support system for the choice of hand-held impulse devices", Science Notes: Mizhvuz. zb. sciences. pr., Luts. Nat. tech. un-t. - Lutsk, No. 46, P. 77-83.

15. Vorobiev, Yu. A., Nechiporuk, N. V. (2017), "Technology of creation of metaontology "Manual impulse devices"", Aviation and space technology i technology, No. 6 (141),P. 4-10.

Received 25.08.2021

Відомості про авторів / Сведения об авторах / About the Authors

Воробйов Юрій Анатолійович - доктор технічних наук, професор, Національний аерокосмічний університет імені М. Є. Жуковського "XАI", декан літакобудівного факультету, Харків, Україна; email: Yuriy.Vorobyov@gmail.com; ORCID: https://orcid.org/0000-0001-6401-7790.

Воробьев Юрий Анатольевич - доктор технических наук, профессор, Национальный аэрокосмический университет имени Н. Е. Жуковского "ХАИ", декан самолетостроительного факультета, Харьков, Украина.

Vorobyov Yuriy - Doctor of Sciences (Engineering), Professor, National Aerospace University "Kharkiv Aviation Institute", Dean of the Aircraft Faculty, Kharkiv, Ukraine.

Шостак Ігор Володимирович - доктор технічних наук, професор, Національний аерокосмічний університет імені M. Є. Жуковського "XAI", професор кафедри інженерії програмного забезпечення, Харків, Україна; email: iv.shostak@gmail.com; ORCID: https://orcid.org/0000-0002-3051-0488.

Шостак Ігорь Владимирович - доктор технических наук, профессор, Национальный аэрокосмический университет имени Н.Е. Жуковского "ХАИ", профессор кафедры инженерии программного обеспечения, Харьков, Украина.

Shostak Igor - Doctor of Sciences (Engineering), Professor, National Aerospace University "Kharkiv Aviation Institute", Professor of the Department of Software Engineering, Kharkiv, Ukraine.

Кривова Світлана Георгї̈вна - кандидат технічних наук, доцент, Національний технічний університет України "Київський політехнічний інститут імені Ігоря Сікорського", доцент кафедри динаміки і міцності машин та опору матеріалів, Київ, Україна; email: skr081077@gmail.com; ORCID: https://orcid.org/0000-1112-5677-3729.

Кривова Светлана Георгиевна - кандидат технических наук, доцент, Национальный технический университет Украины "Киевский политехнический институт имени Игоря Сикорского", доцент кафедры динамики и прочности машин и сопротивления материалов, Киев, Украина.

Kryvova Svetlana - PhD (Engineering Sciences), Associate Professor, National Technical University of Ukraine "Kyiv Polytechnic Institute named after Igor Sikorsky", Associate Professor of the Department of Dynamics and Strength of Machines and Strength of Materials, Kyiv, Ukraine.

Зубаньов Олександр Євгенійович - магістр, АТ "Український науково-дослідний інститут авіаційної технології", провідний інженер, Київ, Україна; email: info@ukrniat.com; ORCID: https://orcid.org/0000-0001-8649-1450.

Зубанев Александр Евгеньевич - магистр, АО "Украинский научно-исследовательский институт авиационной технологии", ведущий инженер, Киев, Украина.

Zubanyov Alexander - Master, JSC "Ukrainian Research Institute of Aviation Technology", Leading Engineer, Kyiv, Ukraine.

\section{РОЗРОБКА ОНТОЛОГІЧНОЇ СИСТЕМИ ІНФОРМАЦИЙНОЇ ПІДТРИМКИ ПРОЦЕСУ ПЕРЕГОВОРІВ ЩОДО КООПЕРАЦИЙНОГО ВИРОБНИЦТВА В ЛІТАКОБУДУВАННІ}

Предмет: засоби інформаційної підтримки процесу проведення переговорів по організації коопераційного виробництва (ПОКВ) повітряних суден (ПС). Мета: викладення процесу розробки ефективних засобів інформаційної підтримки переговорів про коопераційне виробництво, які забезпечать економію фінансів, по-перше, за рахунок скорочення термінів переговорів, а по-друге - зниження ймовірності прийняття нераціональних рішень, що призведуть до додаткових витрат при 
реалізації проекту. Завдання: Підвищення ефективності процесу проведення переговорів щодо організації коопераційного виробництва, за рахунок створення проблемно-орієнтованого методичного базису, а на цій основі - програмних засобів розробки, розгортання і експлуатації відповідної системи підтримки прийняття рішень. Методи: системний аналіз та теорія множин, для формального представлення релевантної інформації щодо предметної галузі "Переговори про коопераційне виробництво повітряних суден"; онтологічний інжиніринг, зокрема стандарт IDEF5, а також елементи технології експертних систем для побудови онтологічної системи підтримки прийняття рішень (ОСППР). Результати: розроблено комплекс методичних засобів розроблення онтологічних систем підтримки прийняття рішень в ході проведення переговорів про організацію кооперативного виробництва (КВ) повітряних суден (ПС); наведено сценарний приклад організації онтологічного діалогу у середовищі ОСППР щодо визначення моделі ПС як об'єкту КВ. Висновки: показана необхідність доповнення математичного забезпечення традиційних систем підтримки переговорів спеціальними методичними засобами для підвищення ефективності інформаційної підтримки процесу переговорів щодо організації кооперативного виробництва в літакобудуванні; обгрунтовано, що для програмної реалізації системи інформаційної підтримки ПОКВ) доцільне використання онтологічного підходу; запропоновано інтелектуальне ядро онтологічної системи підтримки прийняття рішень щодо процесу ПОКВ) ПС побудувати у формі ієрархії фреймів з організацією виведення на знаннях за допомогою приєднаних процедур; наведено сценарний приклад формування рішення щодо вибору моделі ПС для організації КВ у середовищі ОСППР.

Ключові слова: літакобудування; коопераційне виробництво; система підтримки прийняття рішень; онтологічний підхід; фреймова ієрархія; особа, яка приймає рішення

\section{РАЗРАБОТКА ОНТОЛОГИЧЕСКОЙ СИСТЕМЫ ИНФОРМАЦИОННОЙ ПОДДЕРЖКИ ПРОЦЕССА ПЕРЕГОВОРОВ О КООПЕРАЦИОННОМ ПРОИЗВОДСТВЕ В САМОЛЕТОСТРОЕНИИ}

Предмет: средства информационной поддержки процесса проведения переговоров по организации кооперационного производства (ПОКП) воздушных судов (ВС). Цель: изложение процесса разработки эффективных средств информационной поддержки переговоров о кооперационном производстве, которые обеспечат экономию финансов, во-первых, за счет сокращения сроков переговоров, а во-вторых - снижения вероятности принятия нерациональных решений, которые могут привести к дополнительным затратам при реализации проекта. Задача: Повышение эффективности процесса проведения переговоров по организации кооперационного производства, за счет создания проблемно-ориентированного методического базиса, а на этой основе - программных средств разработки, развертывания и эксплуатации соответствующей системы поддержки принятия решений. Методы: системный анализ и теория множеств, для формального представления релевантной информации о предметной области "Переговоры о кооперационном производстве воздушных судов"; онтологический инжиниринг, в частности стандарт IDEF5, а также элементы технологии экспертных систем, для построения онтологической системы поддержки принятия решений (ОСППР). Результаты: разработан комплекс методических средств синтеза онтологических систем поддержки принятия решений в ходе проведения ПОКП ВС, приведен сценарный пример организации онтологического диалога в среде ОСППР по определению модели ВС как объекта кооперационного производства. Выводы: показана необходимость дополнения математического обеспечения традиционных систем поддержки переговоров специальными методическими средствами, для повышения эффективности информационной поддержки процесса переговоров по организации кооперативного производства в самолетостроении; обосновано, что для программной реализации системы информационной поддержки ПОКП целесообразно использование онтологического подхода; предложена архитектура интеллектуального ядра ОСППР по организации процесса ПОКП ВС в форме иерархии фреймов, с организацией вывода на знаниях с помощью присоединенных процедур; приведен сценарный пример формирования решения по выбору модели ВС для организации кооперационного производства в среде ОСППР.

Ключевые слова: самолетостроение; кооперационное производство; система поддержки принятия решений; онтологический подход; фреймовая иерархия; лицо, принимающее решения

\section{Бібліографічні описи / Bibliographic descriptions}

Воробйов Ю. А., Шостак І. В., Кривова С. Г., Зубаньов О. Є. Розробка онтологічної системи інформаційної підтримки процесу переговорів щодо коопераційного виробництва в літакобудуванні. Сучасний стан наукових досліджень та технологій в промисловості. 2021. № 3 (17). С. 5-12. DOI: https://doi.org/10.30837/ITSSI.2021.17.005

Vorobyov, Yu., Shostak, I., Kryvova, S., Zubanyov, A. (2021), "Development of ontological decision making system of the negotiation process on cooperation production in aircraft", Innovative Technologies and Scientific Solutions for Industries, No. 3 (17), P. 5-12. DOI: https://doi.org/10.30837/ITSSI.2021.17.005 